\title{
Behavioural ArChitecture StUdy ON THE Design OF SOCIAL REHABILITATION CENTER FOR THE BLIND AT SURAKARTA
}

\section{Kajian Arsitektur Perilaku Pada Strategi Perancangan PUSAT ReHABilitasi Sosial Disabilitas Netra di Surakarta}

\author{
Nadia Permatasari ${ }^{1 *}$, Maya Andria Nirawati ${ }^{2 *}$ \\ Program Studi Arsitektur, Fakultas Teknik, Universitas Sebelas Maret ${ }^{1 *}$ \\ Email: nadiapermataa@gmail.com \\ Program Studi Arsitektur, Fakultas Teknik, Universitas Sebelas Maret ${ }^{2 *}$
}

\begin{abstract}
:
Social rehabilitation center for the blind in Surakarta is a learning centre for people who is visually impaired, specifically the totally blinded. This facility provides professional activities program in order to regaining and increasing the skills of people with vision impairment, both individuals, families, and group, to carry out their social function fairly, and to live in harmony with the dignity; for instance, social skill learning, provision of additional skills and knowledge, psychosocial and health rehabilitation services, as well as basic daily activities training in Surakarta. The goal of this research is to create a physical space as a place of rehabilitation and counselling for the blind to live independently by providing a safe, easy, and convenient infrastructure facilities. To meet the goal, the principles of behavioral architecture design will be applied on the concept of the building. Field observation on the blinds' behavior is used as the research method, to analyze what the blind needed so the facility can accommodate them.
\end{abstract}

Keywords: behavioural architecture, disability, visually impaired, social rehabilitation center.

\section{PENDAHULUAN}

Penyandang disabilitas bisa disebut sebagai kaum minoritas terbanyak di dunia. Lebih dari satu milyar penduduk dunia merupakan penyandang disabilitas. Keterbatasan tersebut menjadikan berkurangnya peluang pendidikan dan pekerjaan untuk mereka, sehingga penyandang disabilitas menjadi rentan terhadap kemiskinan, salah satunya Indonesia (Amalia, 2014).

Biro Pusat Statistik (BPS) telah melakukan pendataan pada tahun 2012 tentang Sosial Ekonomi Nasional, jumlah penyandang disabilitas di Indonesia adalah 6.008.661 jiwa, diantaranya 1.780 .200 jiwa penyandang disabilitas netra, 616.387 jiwa penyandang disabilitas tubuh, 472.855 jiwa penyandang disabilitas rungu wicara, 402.817 jiwa penyandang disabilitas grahita/intelektual, dan
170.120 jiwa penyandang disabilitas yang sulit mengurus diri sendiri, serta 2.401 .592 jiwa mengalami disabilitas ganda. Sebagian besar dari mereka hanya berpendidikan tidak sekolah/tidak tamat sekolah dasar (SD) sebesar $59,9 \%$ dan berpendidikan SD sebanyak 28,1\% (Kementerian Sosial RI, 2002).

Berdasarkan data yang telah dijabarkan menunjukkan bahwa pendidikan dan keterampilan bagi penyandang disabilitas masih belum terpenuhi secara menyeluruh, khususnya bagi penyandang disabilitas netra sebagai penyandang disabilitas tunggal terbanyak di Indonesia. Disabilitas Netra adalah individu yang penglihatannya lemah atau akurasi penglihatannya kurang dari 6/60 setelah dikoreksi dan/atau tidak lagi memiliki penglihatan sama sekali (Hallahan \& Kauffman, 1988). 
Usaha rehabilitasi bagi penyandang disabilitas netra meliputi bimbingan sosial, pendidikan, dan vokasional (keterampilan) dinilai sangat mampu dalam menanggulangi permasalahan yang dihadapi oleh penyandang disabilitas netra dalam kehidupan bermasyarakat seperti layaknya masyarakat normal. Rehabilitasi bagi disabilitas netra merupakan usaha untuk mengembalikan dan meningkatkan kemampuan individu, keluarga maupun kelompok, masalah kesejahteraan sosial agar dapat melaksanakan fungsi sosialnya sesuai dengan tingkat kemampuan, pendidikan, dan pengalaman serta mampu mengembangkan potensi yang dimiliki untuk dapat menjalani hidup yang mandiri.

Berdasarkan data dari Badan Pusat Statistik pada Surakarta dalam angka tahun 2012, jumlah penderita Disabilitas Netra di Kota Surakarta konstan bahkan cenderung meningkat setiap tahunnya. Persentase rata-rata kenaikan jumlah penyandang Disabilitas Netra di Kota Surakarta adalah 0,003\%. Sedangkan panti rehabilitasi sosial bagi Disabilitas Netra di Surakarta hanya dapat menampung sekitar $0,2 \%$ dari total penyandang Disabilitas Netra yang ada.

Melihat fenomena yang telah diuraikan sebelumnya, maka dibutuhkan sebuah pusat rehabilitasi sosial bagi penyandang disabilitas netra yang diharapkan dapat menjadi wadah untuk belajar dan bersosialisasi bagi penyandang disabilitas netra khususnya di daerah Surakarta, walaupun tidak menutup kemungkinan bagi penyandang disabilitas netra dari luar kota Surakarta untuk dapat menggunakan pusat rehabilitasi sosial ini. Penyandang disabilitas netra yang diwadahi adalah penyandang disabilitas netra yang mengalami kebutaan sejak lahir dengan usia produktif, yaitu antara 15-64 tahun. Fasilitas yang dirancang di bangunan tersebut harus mengacu pada fasilitas yang aman, nyaman, dan mudah bagi difabel, terutama penyandang disabilitas netra.

Tujuan dari perencanaan dan perancangan Pusat Rehabilitasi Sosial Disabilitas Netra di Surakarta adalah untuk mewujudkan sebuah tempat yang dijadikan sebagai wadah bagi para penyandang disabilitas netra untuk belajar, mengembangkan potensi dan bersosialisasi, dengan sesama penyandang disabilitas netra juga dengan masyarakat, sehingga mereka dapat hidup mandiri, dengan menyediakan fasilitas yang aman, nyaman, dan mudah bagi mereka melalui pendekatan Arsitektur Perilaku.

Kenyamanan lingkungan didapatkan oleh panca indera yaitu penglihatan, pendengaran penciuman, dan perabaan. Hal ini menjadi perhatian karena penyandang disabilitas netra tidak bisa melihat, maka kenyamanan dihadirkan dalam bentuk selain visual (Azzahro, Hedi, \& Nirawati, 2014).

\section{METODE}

Metode pembahasan yang digunakan dalam pembuatan konsep perencanaan dan perancangan Pusat Rehabilitasi Sosial Disabilitas Netra di Surakarta sebagai berikut,

\subsection{Macam dan Teknik Pengumpulan Data}

Macam dan teknik pengumpulan data dibagi menjadi 6 (enam). Pertama adalah data mengenai potensi lokasi tapak, peta pembagian wilayah kota dan jumlah fasilitas perlindungan sosial di kota Surakarta. Ketiga data tersebut diperoleh melalui studi dokumen pada Rencana Tata Ruang Wilayah (RTRW) Kota Surakarta tahun 2011-2031.

Kemudian data jumlah difabel menurut jenis dan kecamatan yang didapatkan melalui studi dokumen pada Surkarta dalam angka tahun 2012. Sedangkan untuk data dan informasi mengenai kondisi infrastruktur kota untuk difabel di kota Surakarta dan kondisi Unit Rehabilitasi Sosial Disabilitas Netra yang sudah ada di Kota Surakarta didapatkan melalui observasi langsung ke lokasi yang disebutkan, dan dilengkapi dengan data lain yang diperoleh dari artikel terkait.

Sehubungan dengan program kegiatan untuk Pusat Rehabilitasi Sosial Disabilitas Netra, data-data didapatkan melalui observasi langsung ke Unit Rehabilitasi Sosial Disabilitas Netra yang ada di Kota Surakarta. Data yang diperoleh kemudian dilengkapi dengan hasil wawancara dengan pengelola Unit Rehabilitasi Sosial Disabilitas Netra serta data yang didapatkan dari situs serta artikel terkait dengan Pusat Rehabilitasi Sosial Disabilitas Netra.

Selanjutnya, data mengenai standar bangunan bagi penyandang disabilitas didapat dari peratutan menteri Pekerjaan Umum dan Perumahan Rakyat (PERMENPUPR) nomor 14 tahun 2017. 
Terakhir adalah data mengenai teori Arsitektur Perilaku yang diperoleh melalui studi literatur buku-buku mengenai Arsitektur Perilaku juga dari artikel terkait.

\subsection{Analisis Perencanaan dan Perancangan}

Proses analisis berupa pengolahan data yang telah dikumpulkan. Analisis perencanaan dilakukan dengan mengidentifikasi permasalahan yang ada pada objek pengamatan. Kemudian dikaji dengan data literatur dan fenomena/isu terkini.

Acuan yang digunakan dalam penyelesaian masalah yaitu menggunakan pendekatan Arsitektur Perilaku baik dalam perencanaan maupun perancangan bangunan. Hasil proses analisis tersebut merupakan bahan perancangan transformasi desain Pusat Rehabilitasi Sosial Disabilitas Netra yang direncanakan.

Analisis perencanaan dilakukan dengan mengidentifikasi permasalahan yang ada pada Pusat Rehabilitasi Sosial Disabilitas Netra dengan menggunakan prinsip-prinsip Arsitektur Perilaku. Penyelesaian masalah tersebut juga dilakukan dengan menggabungkan hasil analisis perilaku penyandang disabilitas netra, program kegiatan, teori Arsitektur Perilaku, serta dengan standar bangunan pusat rehabilitasi sosial bagi disabilitas netra yang ada.

Prinsip Arsitektur Perilaku yang diterapkan meliputi communicative atau komunikatif, meliputi detail arsitektural berupa petunjuk suara, kemudian bentuk bangunan, serta material bangunan sebagai petunjuk arah. Kedua adalah ease atau kemudahan, yang meliputi pengolahan sirkulasi dan pencapaian yang accessible dan identifiable.

Kemudian prinsip Arsitektur Perilaku yang ketiga adalah secure atau keamanan, yang meliputi detail arsitektur berupa handrail (pegangan tangan) serta bentuk bangunan yang aman bagi penyandang disabilitas netra. Lalu ada juga pleasure atau kenyamanan, yang meliputi pencahayaan, penghawaan, dan peruangan.

Prinsip Arsitektur Perilaku yang terakhir adalah aesthetic atau disebut juga estetika. Estetika ini meliputi tampilan bangunan dan perencanaan tapak yang sesuai dengan fungsi bangunan.

\subsection{Skema Desain}

Transormasi desain dalam prosesnya secara umum mengacu pada 5 (lima) prinsip Arsitektur Perilaku yaitu, mampu berkomunikasi, kemudahan, keamanan, kenyamanan, serta estetika bentuk dan komposisi. Proses transformasi desain meliputi penerjemahan hasil analisis perencanaan dan perancangan menjadi desain Pusat Rehabilitasi Sosial Disabilitas Netra.

Skema desain diawali dengan menentukan program kegiatan dan kebutuhan ruang di Pusat Rehabilitasi Sosial Disabilitas Netra. Setelah memperoleh program kegiatan dan kebutuhan ruang, maka akan ditentukan gubahan massa yang dibutuhkan di dalam Pusat Rehabilitasi Sosial Disabilitas Netra. Pengolahan gubahan massa juga mengacu pada prinsip Arsitektur Perilaku dengan mewujudkan massa yang mampu berkomunikasi dengan penggunanya maupun lingkungan, mudah, aman dan nyaman ketika digunakan oleh penggunanya, terutama penyandang disabilitas netra, serta memiliki estetika bentuk dan komposisi yang baik.

\section{HASIL DAN PEMBAHASAN}

\subsection{Analisis Pelaku Kegiatan}

Pelaku kegiatan di Pusat Rehabilitasi Sosial Disabilitas Netra terdiri dari 4 (empat) kategori. Pelaku paling utama pada bangunan ini adalah peserta didik (penyandang disabilitas netra yang mengalami kebutaan sejak lahir dengan usia produktif, yaitu antara 15-64 tahun).

Selanjutnya adalah pengelola Pusat Rehabilitasi Sosial Disabilitas Netra yang terdiri dari kepala Pusat Rehabilitasi Sosial Disabilitas Netra sebagai pemimpin Pusat Rehabilitasi Sosial Disabilitas Netra, seksi pelayanan dan rehabilitasi, Sub. Bagian Tata Usaha (TU), seksi penyaluran, serta pengelola hunian.

Kemudian kategori pelaku kegiatan yang ketiga adalah servis dibagi menjadi 2 (dua) sub bagian yaitu Sub. Bagian kebersihan dan Sub. Bagian keamanan. Dan yang terakhir adalah pengunjung layanan jasa. Kategori pengunjung layanan jasa dibagi menjadi 2 (dua) jenis yaitu pengunjung non formal (keluarga peserta didik) dan pengunjung formal/semi formal (riset/penelitian, pers, instansi luar). 


\subsection{Analisis Perilaku Penyandang Disabilitas Netra}

Penyandang disabilitas netra pada umumnya cenderung memiliki perilaku yang sama atau sebuah stereotype. Perilaku stereotype yang cenderung dimiliki penyandang disabilitas netra adalah sering menekan matanya, menggosok mata secara berlebihan, membuat suara dengan jarinya, menggoyang-goyangkan kepala dan badan, berputar-putar, menutup atau melindungi mata sebelah, memiringkan kepala atau mencondongkan kepala ke depan, berkedip lebih banyak dari biasanya, cepat marah apabila mengerjakan suatu pekerjaan, dan meraba benda di sekitarnya untuk mencari jalan.

Beberapa teori mengungkapkan bahwa penyandang disabilitas netra mengembangkan perilaku-perilaku stereotype tersebut terjadi karena respon dari adanya rangsangan sensoris, terbatasnya kegiatan dan gerak di dalam lingkungan, dan keterbatasan sosial.

\subsection{Analisis Kegiatan}

Kegiatan pada Pusat Rehabilitasi Sosial Disabilitas Netra dibagi menjadi 4 (empat), yang pertama adalah kegiatan utamanya yaitu kegiatan rehabilitasi (bimbingan fisik, bimbingan mental, bimbingan sosial, dan bimbingan keterampilan).

Pelayanan yang diberikan oleh pusat rehabilitasi sosial meliputi jiwa, raga, dan sosial. Oleh karena itu pelayanan rehabilitasi yang dilaksanakan adalah rehabilitasi lengkap yaitu rehabilitasi medik, rehabilitasi sosial psikologi, dan rehabilitasi karya (Kusumaputri, Setyaningsih, \& Mustaqimah, 2014).

Kegiatan rehabilitasi terdiri dari beberapa kegiatan yaitu olahraga, bimbingan kesehatan diri \& lingkungan, orientasi mobilitas, bimbingan budi pekerti, bimbingan agama, bimbingan braille, bimbingan psikososial, terapi kelompok, ADL (Activity Daily Living), pramuka \& rekreasi, bimbingan keterampilan kerajinan tangan (anyaman, sapu, manikmanik), bimbingan keterampilan kewirausahaan, bimbingan keterampilan komputer, bimbingan keterampilan pijat (sport massage dan shiatzu), serta bimbingan keterampilan kesenian (musik dan rupa).

Kedua adalah kegiatan publik (workshop dan layanan jasa). Ada 3 (tiga) kegiatan yang termasuk dalam kegiatan publik yaitu pendaftaran, pemberian informasi, dan workshop.

Kemudian kegiatan hunian. Ketika di hunian, beberapa kegiatan yang dilakukan adalah, bimbingan ADL (Activity Daily Living), makan, bersosialisasi, dan ibadah.

Selanjutnya yang terakhir yaitu kegiatan servis. Kegiatan servis ini terdiri dari menjaga kebersihan lingkungan Pusat Rehabilitasi Sosial Disabilitas Netra juga menjaga keamanan di dalam lingkungan Pusat Rehabilitasi Sosial Disabilitas Netra.

\subsection{Analisis Besaran Ruang}

Tabel 1. Rekapitulasi Kebutuhan Besaran Ruang

\begin{tabular}{|l|r|}
\hline \multicolumn{1}{|c|}{ Kelompok } & \multicolumn{1}{c|}{ Luas Ruangan } \\
\hline Rehabilitasi & $\mathbf{3 7 5 4 , 9 8} \mathbf{~ m}^{\mathbf{2}}$ \\
\hline Publik & $\mathbf{2 4 4 , 5 0} \mathbf{~ m}^{\mathbf{2}}$ \\
\hline Hunian & $\mathbf{1 3 3 4 , 3 6} \mathbf{~ m}^{\mathbf{2}}$ \\
\hline Servis & $\mathbf{2 3 9 , 2 0} \mathbf{~ m}^{\mathbf{2}}$ \\
\hline
\end{tabular}

Rekapitulasi seperti yang ditunjukkan pada Tabel 1 dengan persentase sebagai berikut 67\% dari luas total digunakan untuk area rehabilitasi, 5\% dari luas total digunakan untuk area publik, $24 \%$ dari luas total digunakan untuk area hunian, serta $4 \%$ dari luas total digunakan untuk area servis.

\subsection{Analisis Tapak}

Tapak terpilih untuk Pusat Rehabilitasi Sosial Disabilitas Netra di Surakarta berada di Kecamatan Laweyan, tepatnya di depan Universitas Sahid, Jalan Adi Sucipto. Tapak ini dikelilingi oleh 3 (tiga) jalan lingkungan dan 1 (satu) jalur lambat dari jalan arteri primer yaitu Jalan Adi Sucipto Solo dengan luasan $\pm 2,5 \mathrm{Ha}$. Tapak ini memiliki potensi sebagai lokasi Pusat Rehabilitas Disabilitas Netra di Kota Surakarta karena mudah untuk dicapai dan dekat dengan Rumah Sakit Mata Solo sehingga mempermudah untuk menjalin kerjasama.

Batas tapak sebelah timur laut adalah jalur lambat jalan Adi Sucipto dan Universitas Sahid Surakarta; sebelah barat laut berbatasan dengan jalan lingkungan (Jl. Jambu Raya) dan ruko, sekitar 750 m ke barat laut ada Rumah Sakit Mata Solo; sedangkan sebelah tenggara berbatasan dengan jalan lingkungan (j1. Manggis I) dan pemukiman penduduk; serta pada sebelah barat daya berbatasan dengan jalan lingkungan (jl. Manggis IV), lahan kosong dan sawah. 


\subsection{Persoalan Tapak}

Persoalan tapak meliputi kemudahan akses masuk dan keluar tapak, sirkulasi tapak yang aman dan nyaman serta mudah diakses oleh penggunanya, pejalan kaki memiliki akses sendiri terpisah dengan akses masuk/keluar kendaraan (lihat Gambar 2), pengolahan vegetasi untuk menunjang kegiatan yang ada (lihat Gambar 3), memaksimalkan penggunaan energi alami pada tapak. Aspek yang berperan adalah komunikatif, kemudahan, keamanan, dan kenyamanan.

\section{Main Entrance}

Jalur masuk/keluar bangunan menggunakan sistem satu pintu. Sistem satu pintu ini lebih mudah dipantau hanya melalui satu pos keamanan.

\section{Sirkulasi Luar Bangunan}

Sirkulasi kendaraan masuk dan keluar tapak menggunakan pola sirkulasi linier. Sirkulasi kendaraan ini terbagi menjadi 5 (lima) macam yaitu sirkulasi mobil pengunjung dan pengelola, sirkulasi motor pengunjung, sirkulasi pejalan kaki, sirkulasi motor pengelola, dan sirkulasi kendaraan servis (lihat Gambar 1).

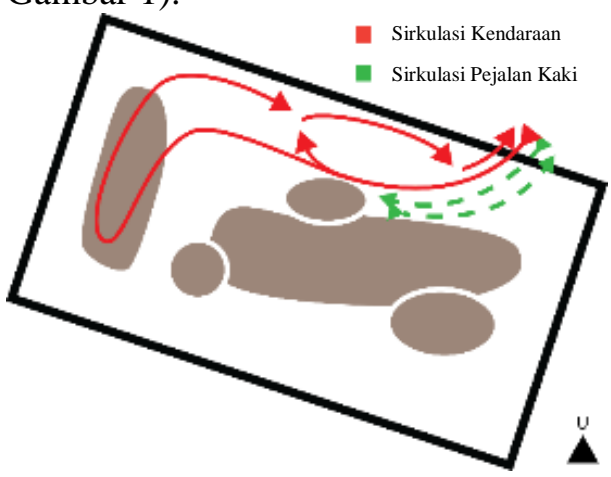

Gambar 1. Pola Sirkulasi di Luar Bangunan

3. Lansekap

Elemen taman yang mampu mengakomodasi kesenangan psikologi dapat diterapkan melalui penataan tanaman/vegetasi yang beragam. Penataan lansekap dibagi menjadi 2 (dua) yaitu softscapes dan hardscapes. Softscapes yang digunakan ada 3 (tiga) jenis yaitu vegetasi peneduh (pohon akasia \& pohon angsana), vegetasi penyejuk (pohon mangga $\&$ tanaman hias yang memiliki bunga), dan penutup tanah (rumput gajah). Elemen hardscapes yang digunakan berupa aspal, paving block, dan keramik.

\subsection{Analisis Lingkungan}

Analisis lingkungan yang dimaksud yaitu analisis sinar/cahaya matahari, analisis arah angin, analisis pencapaian dan analisis kebisingan.

1. Analisis Sinar/Cahaya Matahari

Lokasi tapak dikelilingi dengan bangunanbangunan rendah, sehingga Pusat Rehabilitasi Sosial Disabilitas Netra akan menerima paparan langsung sinar matahari. Analisis ini akan menghasilkan zonasi berdasarkan pergerakan matahari pada Gambar 2.

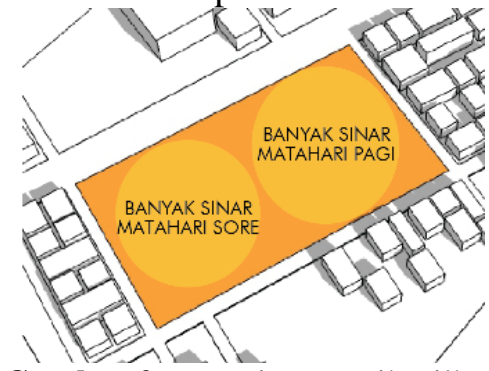

Gambar 2. Zonasi yang Dihasilkan

2. Analisis Arah Angin

Ruang-ruang pada bangunan Pusat Rehabilitasi Sosial Disabilitas Netra yang direncanakan dapat memanfaatkan penghawaan alami sebagai penghawaan dalam bangunan untuk mengurangi penghawaan buatan. Oleh karena itu pergerakan angin juga menjadi elemen penting dalam penentuan zonasi ruang. Umumnya, di Kota Surakarta angin bertiup dari arah selatan atau barat daya (lihat Gambar 3) sehingga menghasilkan zonasi seperti yang ditunjukkan pada Gambar 4.

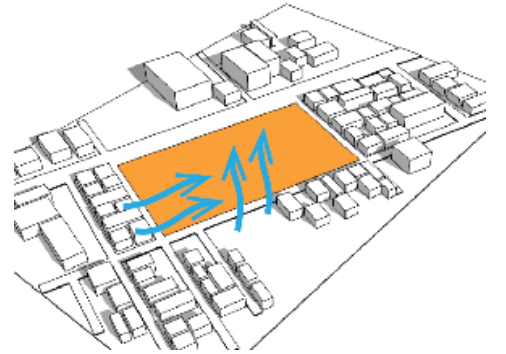

Gambar 3. Analisis Pergerakan Arah Angin

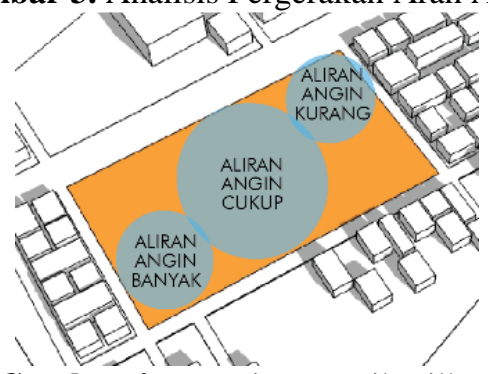

Gambar 4. Zonasi yang Dihasilkan 


\section{Analisis Pencapaian}

Akses utama ME menuju tapak dicapai dari jalan Adi Sucipto Solo melalui jalur lambat di depan tapak. Bangunan bukan merupakan bangunan komersial, sehingga alur keluarmasuk kendaraan tidak terlalu ramai, sistem keluar-masuk satu pintu diaplikasikan dengan pertimbangan keamanan sehingga alur keluarmasuk kendaraan lebih mudah dipantau melalui satu pos keamanan (lihat Gambar 5) yang kemudian akan menghasilkan zonasi seperti yang ditunjukkan pada Gambar 6 .

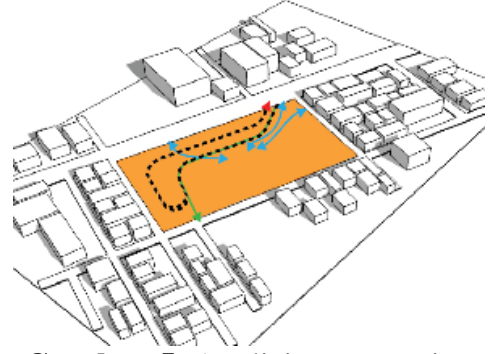

Gambar 5. Analisis Pencapaian

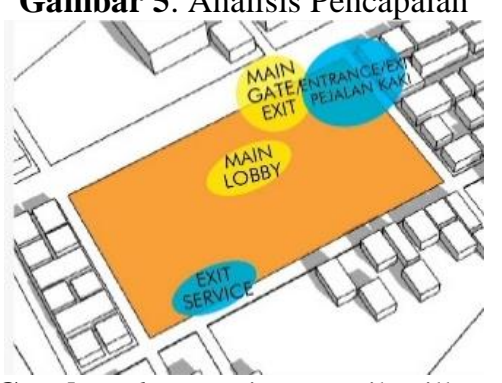

Gambar 6. Zonasi yang Dihasilkan

\section{Analisis Kebisingan}

Tapak terletak di jalan arteri yaitu jl. Adi Sucipto, sehingga ada sisi tapak yang terkena kebisingan tinggi dari lalu lintas jalan tersebut.

Kebisingan paling tinggi terdapat pada sisi timur laut tapak, sedangkan 3 sisi lainnya terkena kebisingan rendah yang berasal dari jalan lingkungan (lihat Gambar 7). Analisis ini menghasilkan zonasi seperti yang ditunjukkan pada Gambar 8.

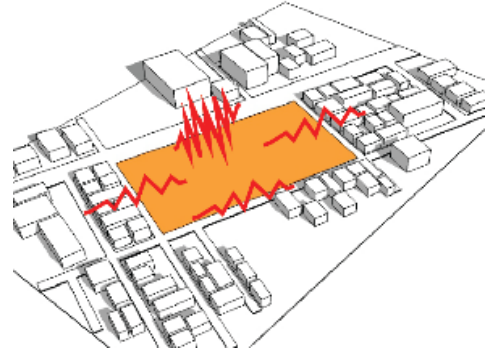

Gambar 7. Analisis Pencapaian

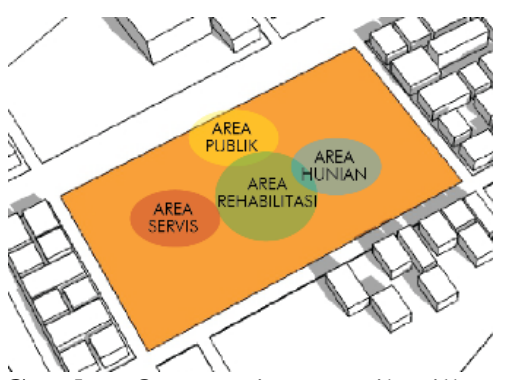

Gambar 8. Zonasi yang Dihasilkan

\subsection{Persoalan Peruangan}

Persoalan peruangan meliputi pengelolaan sirkulasi yang aman, nyaman dan mudah, zonasi ruang untuk menciptakan suasana yang fokus dan nyaman, serta meminimalisir permainan elevasi lantai. Aspek yang berperan adalah komunikatif, kemudahan, keamanan, dan kenyamanan.

Zonasi ruang merupakan hasil gabungan dari beberapa analisis seperti analisis lingkungan, analisis kegiatan, dan analisis pola sirkulasi bangunan. dibagi menjadi 5 (lima) area yaitu area penerimaan, area rehabilitasi, area hunian, area servis, dan area parkir (lihat Gambar 9).

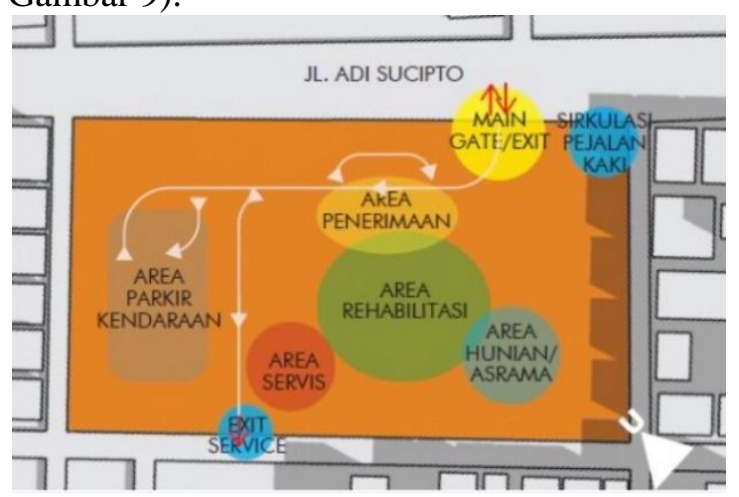

Gambar 9. Zonasi Ruang Akhir

\subsection{Persoalan Bentuk dan Tata Massa Bangunan}

Persoalan bentuk dan tata massa bangunan meliputi meminimalisir sudut-sudut tajam, bentuk menyesuaikan sirkulasi dan fungsi ruang, penggunaan material bangunan yang aman, serta tampilan bangunan sesuai dengan lokasi tapak. Aspek yang berperan adalah komunikatif, keamanan, dan estetika. 


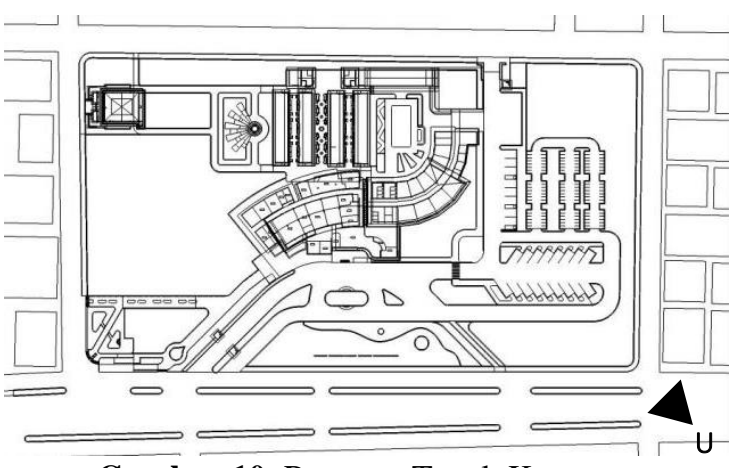

Gambar 10. Rencana Tapak Kawasan

Rencana Tapak pada Gambar 10 merupakan hasil gabungan dari beberapa analisis seperti analisis besaran ruang, tapak, pengolahan tapak, pencapaian dan sirkulasi, serta sistem struktur dan sistem utilitas. Desain ini berdasarkan kriteria kemudahan akses, keamanan, dan kenyamanan bagi penggunanya, terutama peserta didik.

Selanjutnya mengenai bentuk bangunan. Bentuk bangunan Pusat Rehabilitasi Sosial Disabilitas Netra ini didominasi dengan sudutsudut tumpul atau lengkung (lihat Gambar 11). Hal ini diaplikasikan dalam rangka perwujudan prinsip desain Arsitektur Perilaku terutama keamanan.

Terakhir mengenai tampilan bangunan. Lokasi tapak terletak di Surakarta yang hanya memiliki 2 (dua) musim yaitu musim panas dan hujan. Oleh karena itu tampilan bangunan yang sesuai adalah arsitektur jawa dan dikombinasikan dengan arsitektur modern untuk lebih terlihat dinamis. Atap yang digunakan adalah atap pelana (lihat Gambar $11)$.

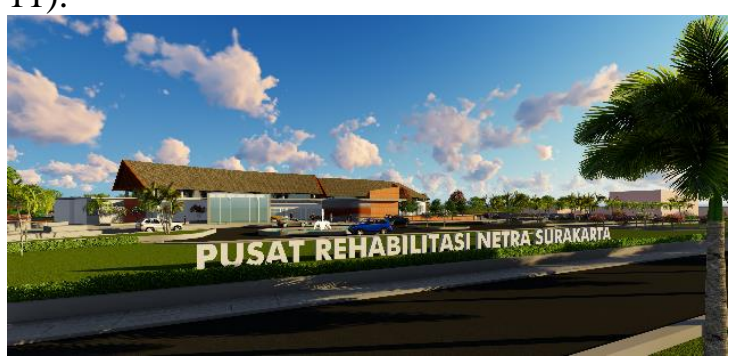

Gambar 11. Perspektif Bangunan dari Jalan Adi Sucipto Solo

\subsection{Analisis Sarana Prasarana}

Terdapat 5 (lima) sarana prasarana utama yang direncanakan pada Pusat Rehabilitasi Sosial Disabilitas Netra ini.

Pertama adalah handrail atau pegangan tangan. Pegangan tangan ditempatkan pada ketinggian yang aman dan nyaman untuk digunakan. Pegangan tangan dibagi menjadi 2 (dua) jenis, yaitu untuk dewasa dan anak-anak. Perbedaan diantara keduanya adalah ketinggian dan diameter pegangan nya. Pegangan untuk dewasa memiliki ketinggian $80 \mathrm{~cm}$ dari lantai, sedangkan untuk anak-anak $65 \mathrm{~cm}$ dari lantai (Menteri Pekerjaan Umum, 2006).

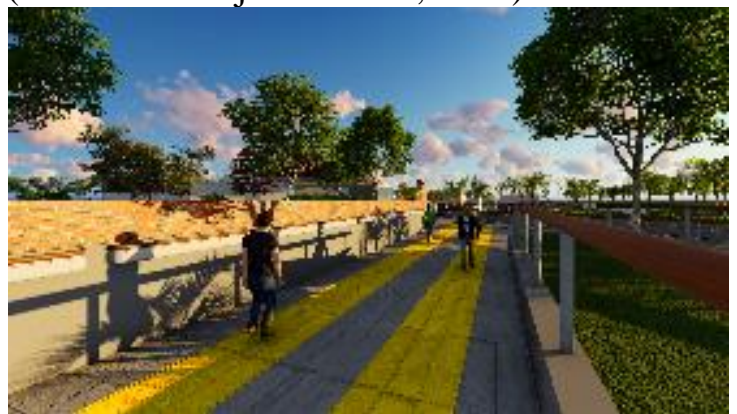

Gambar 12. Perspektif Pedestrian

Handrail diberikan pada setiap koridor juga pedestrian (lihat Gambar 12).

Kedua adalah tacticle guideline. Sarana prasarana ini berfungsi sebagai penunjuk arah. Area yang dilengkapi dengan tacticle guideline yaitu area koridor dan pedestrian. Contoh penerapan tacticle guideline di pedestrian dapat dilihat pada Gambar 12. Sedangkan untuk keyplan tacticle guideline ada pada Gambar 13.

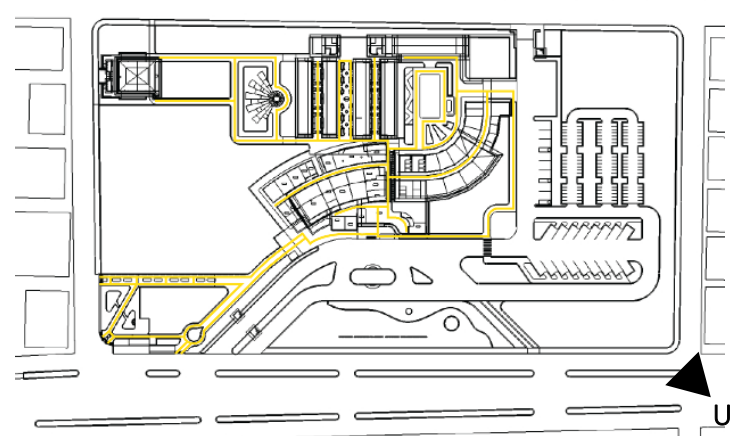

Gambar 13. Keyplan Material Lantai Tacticle Guideline

Ketiga adalah petunjuk nama ruangan berupa petunjuk raba yang menggunakan huruf braille (lihat Gambar 14).

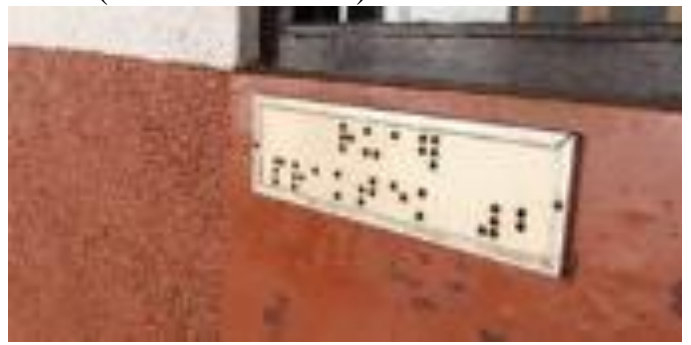

Gambar 14. Petunjuk Braille di Depan Ruang 
Keempat adalah penggunaan ramp. Ramp dibutuhkan untuk menunjang mobilitas peserta didik yang menggunakan kursi roda. Sudut kemiringan ramp maksimal 6\% (Neufert \& Neufert, 1970).

Kelima adalah alarm. Alarm atau rambu verbal berfungsi sebagai penanda ruang yang dapat bersuara ketika dipencet tombol yang ada di alarm tersebut (lihat Gambar 15).

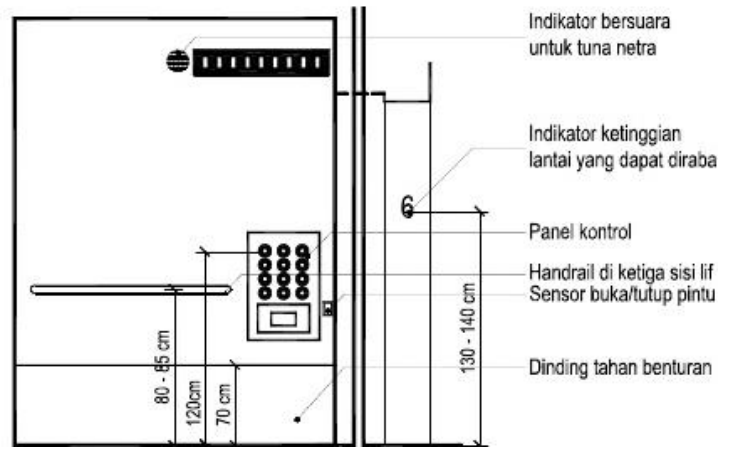

Gambar 15. Penanda Ruang untuk Disabilitas Netra

Sumber: Menteri Pekerjaan Umum, 2006

\subsection{Analisis Sistem Struktur}

Sistem upper structure yang digunakan pada bangunan yang direncanakan adalah rangka baja ringan sebab bangunan ini memiliki bentang yang lebar. Sistem upper structure yang digunakan pada bangunan yang direncanakan adalah struktur rangka karena fleksibilitas penggunaan ruangnya menjadi cukup tinggi. Selain itu, penggunaan kolomkolom sebagai struktur badan bangunan memungkinkan banyaknya bukaan-bukaan pada bangunan. Sub structure yang digunakan adalah pondasi batu kali dan footplat. Kedua pondasi tersebut paling cocok digunakan untuk bangunan Pusat Rehabilitasi Sosial Disabilitas Netra di Surakarta karena dapat dipersiapkan untuk perkembangan bangunan secara vertikal.

\section{KESIMPULAN}

Pusat Rehabilitasi Sosial Disabilitas Netra berfungsi sebagai wadah bagi penyandang disabilitas netra dalam memperoleh terapi sosial dan mental, pendidikan, serta penggalian dan pengembangan minat dan bakat penyandang disabilitas sehingga dapat mandiri dan mengembalikan fungsi sosialnya secara optimal dalam kehidupan bermasyarakat. Arsitektur Perilaku digunakan sebagai pendekatan desain untuk mewujudkan bangunan yang dapat mengakomodasi perilaku penyandang disabilitas netra.

Terdapat 5 (lima) aspek Arsitektur Perilaku yang diterapkan dalam perencanaan dan perancangan Pusat Rehabilitasi Sosial Disabilitas Netra ini yaitu communicative (komunikatif), ease (kemudahan), secure (keamanan), pleasure (kenyamanan), serta aesthetic (estetika). Lima aspek ini masingmasing berperan dalam menyelesaikan persoalan-persoalan dalam perencanaan dan perancangan. Terpilih beberapa elemen utama yang menjadi pembahasan penerapan Arsitektur Perilaku dari banyak elemen yang terdapat pada bangunan Pusat Rehabilitasi Sosial Disabilitas Netra yaitu persoalan tapak, persoalan peruangan, persoalan bentuk \& tata massa bangunan, serta analisis sarana prasarana.

Sarana prasarana utama khusus penyandang disabilitas netra adalah handrail/pegangan tangan, tacticle guideline, petunjuk raba berupa plakat petunjuk ruang dengan tulisan braille, serta alarm/rambu verbal sebagai penanda ruang yang dapat bersuara.

\section{REFERENSI}

Amalia, A. D. (2014). Evaluasi Outcomes Bagi Individu Program Rehabilitasi Sosial Disabilitas Netra: Studi Kasus Empat Alumni PSBN Wyata Guna Bandung. INFORMASI Vol.19 No.3, 260-283.

Azzahro, A. L., Hedi, D., \& Nirawati, M. A. (2014). Pusat Pembinaan Tuna Netra dan Tuna Rungu untuk Anak dan Remaja di Surakarta dengan Penerapan Metode Terapi Bermain Melalui Aspek Psikologi Ruang. Arsitektura, Vol. 12, No. 2.

Hallahan, D. P., \& Kauffman, J. M. (1988). EXCEPTIONAL CHILDREN:

Introduction to Special Education. New Jersey: Prentice Hall Division of Simon \& Schuster.

Kementerian Sosial RI. (2002). Pelayanan Penyandang Disabilitas Dalam Menggunakan Berbagai Sarana Aksebilitas. Retrieved from Kementrian Sosial RI: http://www.kemsos.go.id/modules.php ?name $=$ News $\&$ file $=$ article $\&$ sid $=18765$ 
Kusumaputri, R. L., Setyaningsih, W., \& Mustaqimah, U. (2014). Balai Rehabilitasi Sosial bagi Disabilitas Fisik (Tuna Netra, Tuna Rungu Wicara, dan Tuna Daksa) di Surakarta. Arsitektura, Vol. 12, No. 1.

Menteri Pekerjaan Umum. (2006). Peraturan menteri pekerjaan umum No.30.

Neufert, E., \& Neufert, P. (1970). Architects' Data. Germany. 